\title{
Expression and In Vitro Functions of the Ghrelin Axis in Endometrial Cancer
}

\author{
Jenny N. T. Fung • Inge Seim • Dengfeng Wang • \\ Andreas Obermair · Lisa K. Chopin • Chen Chen
}

Published online: 23 November 2010

(C) Springer Science+Business Media, LLC 2010

\begin{abstract}
Ghrelin is a peptide hormone produced in the stomach and a range of other tissues, where it has endocrine, paracrine and autocrine roles in both normal and disease states. Ghrelin has been shown to be an important growth factor for a number of tumours, including prostate and breast cancers. In this study, we examined the expression of the ghrelin axis (ghrelin and its receptor, the growth hormone secretagogue receptor, GHSR) in endometrial cancer. Ghrelin is expressed in a range of endometrial cancer tissues, while its cognate receptor, GHSR1a, is expressed in a small subset of normal and cancer tissues. Low to moderately invasive endometrial cancer cell lines were examined by RT-PCR and immunoblotting, demonstrating that ghrelin axis mRNA and protein expression correlate with differentiation status of Ishikawa, HEC1B and KLE endometrial cancer cell lines. Moreover, treatment with ghrelin potently stimulated cell proliferation and inhibited cell death. Taken together, these data indicate that ghrelin promotes the progression of endometrial cancer cells in vitro, and may contribute to endometrial cancer pathogenesis and represent a novel treatment target.
\end{abstract}

J. N. T. Fung $\cdot$ D. Wang $\cdot$ C. Chen $(\triangle)$

Department of Physiology and Pharmacology,

School of Biomedical Sciences, The University of Queensland,

Brisbane QLD 4072, Australia

e-mail: chen.chen@uq.edu.au

I. Seim $•$ L. K. Chopin

Ghrelin Research Group, Institute of Health and Biomedical Innovation and School of Life Sciences,

Queensland University of Technology,

Brisbane QLD 4000, Australia

\section{A. Obermair}

University Queensland Central Clinical Division,

Queensland Centre for Gynaecological Cancer,

Queensland, Australia
Keywords Ghrelin · Growth hormone secretagogue receptor Endometrial cancer P Proliferation - Antiapoptosis $\cdot$ Differentiation

\section{Introduction}

Endometrial cancer is the fourth most frequent cancer among women and is now the most common gynaecological cancer in many developed countries. It is a significant cause of morbidity and mortality in the advanced stages of the disease [1]. Despite being a common malignancy, treatment of endometrial cancer has changed little in the last few decades [2]. Advances in molecular biology, however, have led to the discovery and development of more targeted therapeutics for the disease [3].

The human uterine endometrium, unlike most other normal tissue, is specialised and undergoes sequential phases of proliferative and secretory changes throughout the female menstrual cycle in preparation for embryonic implantation or shedding [4]. These processes of endometrial tissue remodelling are precisely controlled by various growth factors and ovarian hormones [5]. While insulinlike growth factors (IGFs) [6], oestrogen [7], progesterone [8] and growth hormones (GH) $[9,10]$ are implicated in normal endometrial development, it is highly likely that ghrelin and its receptor are also involved [11-14].

The 28-amino-acid peptide hormone ghrelin is posttranslationally modified to give rise to a unique $n$-octanoylated (acylated) peptide that is an endogenous ligand for the growth hormone secretagogue receptor (GHSR1a) [15]. A GHSR isoform, GHSR1b, generated by alternative splicing, has been thought to be devoid of any endocrine activity due to its inability to bind any growth hormone secretagogues, and its functional role is yet to be fully elucidated [16]. Both ghrelin 
and its cognate receptor have been detected in a number of peripheral tissues, including the lung, testis, ovary, breast, prostate and endometrium $[17,18]$, suggesting that co-localised ghrelin and GHSR has potential autocrine/paracrine regulatory effect in these tissues. Recently, compelling evidence has arisen demonstrating that ghrelin is also involved in a range of reproductive processes, including steroid hormone regulation, embryo implantation and endometrial tissue remodelling $[11,13,19]$. Previous work from our group demonstrated expression of ghrelin and GHSR in human endometrium during the menstrual cycle [12]. Levels of both ghrelin and receptor mRNA and protein were highest in the secretory phase, where the endometrium is thickened, while the lowest expression was seen in the menstrual phase, where the endometrium is shedding. This suggests that the ghrelin axis is potentially involved in the extensive cyclical growth and development in endometrial tissues.

In addition to regulating the normal growth and differentiation of tissues, ghrelin has been implicated in the maintenance and progression of several human cancers. Ghrelin and/or the expression of GHSR has been demonstrated in a number of hormone-dependent cancers, including breast [20], testicular [21] and prostate cancer [22], suggesting a possible autocrine and/or paracrine role for ghrelin in cancer cell growth. It has been reported that exogenously applied ghrelin increases the rate of cell growth in prostate $[22,23]$ and breast cancer cell lines [20].

As ghrelin is expressed in normal endometrial tissues and ghrelin has functions in other endocrine-related cancers, we hypothesised that a similar system could exist in endometrial cancer. The aim of the present study was to investigate the expression of ghrelin and GHSR in human endometrial cancer and to investigate the ability of exogenous ghrelin to alter proliferation and survival in endometrial cancer cell lines.

\section{Materials and Methods}

\section{Endometrial Cancer Specimens}

Endometrial tissue quantitative RT-PCR arrays were purchased from OriGene (Rockville, MD, USA). This array consisted of pathologist-verified samples from eight normal endometrial tissues and 40 different endometrial tumours (TissueScan Endometrial Cancer Tissue qPCR Panel II; OriGene). Ages of tissue donors ranged from 31 to 86 years. In addition, four archival tissue specimens were obtained from affiliated hospitals. Briefly, endometrial cancer biopsies $(n=2)$ from stage I endometrioid adenocarcinomas of the endometrium were collected from patients undergoing hysterectomy at the Greenslopes Private Hospital (Queensland, Australia). Normal endo- metrial tissue biopsies $(n=2)$ were obtained from healthy controls in patients undergoing surgery for uterine fibroids at the gynaecological department of the West China Second Hospital at Sichuan University. The tissue collection protocol was approved by the associated human research ethics committees. Written informed consent was obtained from all patients on the study. All biopsies were examined and verified by gynaecological pathologists. Tissues were snapfrozen on dry ice and stored at $-80^{\circ} \mathrm{C}$ until RNA extraction was performed.

\section{Cell Culture}

The well-differentiated Ishikawa endometrial cancer cell line, moderately differentiated line HEC1B cell line, and poorly differentiated KLE cell line were obtained from the American Type Culture Collection (Rockville, MD, USA). All endometrial cancer cell lines were cultivated in DMEM/ F12 medium (Sigma-Aldrich, St. Louis, MO, USA) containing $10 \%$ foetal bovine serum (Thermo Scientific HyClone, Canada), $50 \mathrm{U} / \mathrm{ml}$ penicillin and $50 \mu \mathrm{g} / \mathrm{ml}$ streptomycin (Invitrogen, Carlsbad, CA, USA), and grown in a humidified atmosphere containing $5 \% \mathrm{CO}_{2}$ at $37^{\circ} \mathrm{C}$. All cell lines were tested to be free from Mycoplasma contamination.

RNA Extraction and Reverse Transcriptase PCR (RT-PCR)

Total RNA was isolated from frozen tissues (post-liquid nitrogen processing) and cell lines using a TRIzol Plus RNA Purification kit (Invitrogen), and tissue was homogenised by passing it through 26 gauge needles. Total RNA $(1 \mu \mathrm{g})$ was reverse transcribed in a $20-\mu l$ reaction using iScript cDNA Synthesis kit (Bio-Rad Laboratories) according to the manufacturer's instructions. Negative controls were prepared by omitting reverse transcriptase (no-RT control) or by the substitution of water for the template. Messenger RNA (mRNA) expression for ghrelin, GHSR1a and GHSR $1 b$ was examined in endometrial cancer cell lines and tissues using JumpStart Taq DNA polymerase (Sigma) and a conventional thermal cycler (Corbett Research, Concorde, NSW, Australia) according to the manufacturer's instructions. For ghrelin and GHSR1b, the primers and reaction conditions were as described previously [19, 24]. Briefly, thermal cycling consisted of $1 \mathrm{~min}$ at $94^{\circ} \mathrm{C}, 36$ cycles of $10 \mathrm{~s}$ at $98^{\circ} \mathrm{C}, 30 \mathrm{~s}$ at $53^{\circ} \mathrm{C}, 45 \mathrm{~s}$ at $72^{\circ} \mathrm{C}$ (ghrelin) or 35 cycles of $20 \mathrm{~s}$ at $98^{\circ} \mathrm{C}, 30 \mathrm{~s}$ at $58^{\circ} \mathrm{C}, 1 \mathrm{~min}$ at $72^{\circ} \mathrm{C}$ (GHSR 1b), followed by $10 \mathrm{~min}$ at $72^{\circ} \mathrm{C}$. For GHSR1a, primers were designed manually from the NCBI Reference Sequence (NM_198407) and thermal cycling consisted of $1 \mathrm{~min}$ at $94^{\circ} \mathrm{C}, 40$ cycles of $30 \mathrm{~s}$ at $94^{\circ} \mathrm{C}, 30 \mathrm{~s}$ at $61^{\circ} \mathrm{C}$, $1 \mathrm{~min}$ at $72^{\circ} \mathrm{C}$, followed by $10 \mathrm{~min}$ at $72^{\circ} \mathrm{C}$. Additional noRT and no cDNA template (water) controls were included. 
The identity of all amplicons was confirmed by DNA sequencing Briefly, RT-PCR products were purified for direct sequencing using the MinElute PCR purification kit (QIAGEN, Hilden, Germany) and sequenced in both directions (using the primers described earlier) by the Australian Genome Research Facility (AGRF, Brisbane, Australia) using the ABI PRISM BigDye Terminator Cycle Sequencing Kit v3.1 protocol (Applied Biosystems, AB, Foster City, CA, USA).

\section{Quantitative Real-Time RT-PCR}

Endometrial tissue panels supplied by OriGene were interrogated by real-time RT-PCR using the $\mathrm{AB} 7000$ sequence detection system $(\mathrm{AB})$ in a total reaction volume of $20 \mu \mathrm{l}$ using Platinum Quantitative PCR SuperMix-UDG w/ROX (Invitrogen) for ghrelin, while GHSRIa and the housekeeping gene $\beta$-actin were amplified using $2 \times$ SYBR green master mix (AB). Primers for $\beta$-actin were supplied with the cDNA panel (OriGene), while the primers for GHSR $1 a$ are shown in Table 1. Primers and TaqMan probes for ghrelin (Hs01074051_g1, spanning the ghrelin-peptide coding exons) were obtained from Applied Biosystems (AB). Each gene was evaluated on separate, identical array plates, which were loaded with equal amounts of cDNA per well - as described by the manufacturer. Ghrelin was normalised against $\beta$-actin, and fold changes were quantified

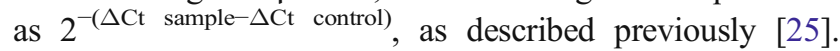
Real-time RT-PCR of endometrial cancer cell lines was carried out using $2 \times$ SYBR green master mix $(\mathrm{AB})$ using the StepOne ${ }^{\mathrm{TM}}$ Real-Time PCR System (AB) according to the manufacturer's instructions. The primer sequences for ghrelin, GHSRIa and GHSRIb are shown in Table 1. The experiments were repeated three times and each experiment was performed in triplicate and normalised against the reference primer set (18S ribosomal RNA). Data was analysed using

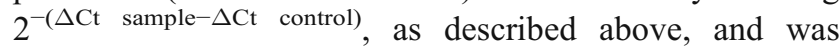
represented as fold-change, compared with the calibrator, the well-differentiated Ishikawa endometrial cancer cell line.

\section{Protein Extraction}

Cultured cells $\left(1 \times 10^{7}\right)$ were harvested and extracted in $500 \mu \mathrm{l}$ lysis buffer $(150 \mathrm{mM}$ sodium chloride, $50 \mathrm{mM}$ Tris- $\mathrm{HCl}, 1 \%$ nonyl phenoxylpolyethoxylethanol and $1 \times$ complete protease inhibitor; Roche Diagnostics, Germany) and phosphatase inhibitors ( $10 \mathrm{nM}$ sodium fluoride, $1 \mathrm{mM}$ sodium orthovanadate and $10 \mathrm{mM}$ tetrasodium pyrophosphate) and cleared by $12,000 \times g$ centrifugation at $4^{\circ} \mathrm{C}$.
Table 1 RT-PCR and quantitative real-time RT-PCR primer sequences, annealing temperatures $\left(T_{\mathrm{a}}\right)$ and expected amplicon size

\begin{tabular}{|c|c|c|c|}
\hline Transcript & Primer sequence & $T_{\mathrm{a}}\left({ }^{\circ} \mathrm{C}\right)$ & Expected size (bp) \\
\hline \multicolumn{4}{|l|}{ RT-PCR } \\
\hline \multicolumn{4}{|l|}{ Ghrelin $^{\mathrm{a}}$} \\
\hline sense & 5'-TGAGCCCTGAACACCAGAGAG-3' & 58 & 327 \\
\hline antisense & 5'-AAAGCCAGATGAGCGCTTCTA-3' & & \\
\hline \multicolumn{4}{|l|}{ GHSR1a } \\
\hline sense & 5'-CTACTTCGCCATCTGCTTCC-3' & 61 & 398 \\
\hline antisense & 5'-GGATGAAGGCAAACACCACT-3' & & \\
\hline \multicolumn{4}{|l|}{ GHSR $1 b^{b}$} \\
\hline sense & 5'-CTTGGGACACCAACGAGTG-3' & 53 & 262 \\
\hline antisense & 5'-AGGACCCGCGAGAGAAAGC-3' & & \\
\hline \multicolumn{4}{|c|}{ Quantitative real-time PCR } \\
\hline \multicolumn{4}{|c|}{ Ghrelin $^{\mathrm{c}}$} \\
\hline sense & 5'-GGGCAGAGGATGAACTGGAA-3' & & \\
\hline antisense & 5'-CCTGGCTGTGCTGCTGGTA-3' & & \\
\hline \multicolumn{4}{|l|}{ GHSR1a } \\
\hline sense & 5'-AGTGGTGTTTGCCTTCATCC-3' & & \\
\hline antisense & 5'-TGATGGCAGCACTGAGGTAG-3' & & \\
\hline \multicolumn{4}{|l|}{${\text { GHSR } 1 b^{c}}^{c}$} \\
\hline sense & 5'-TCGTGGGTGCCTCGCT-3' & & \\
\hline antisense & 5'-GCTGAGACCCACCCAGCA-3' & & \\
\hline \multicolumn{4}{|l|}{18 sRNA $^{\mathrm{d}}$} \\
\hline sense & 5'-TCGGAACTGAGGCCATGAT-3' & & \\
\hline antisense & 5'-CGAACCTCCGACTTTCGT-3' & & \\
\hline
\end{tabular}

${ }^{\text {a }}$ Gualillo et al. [19]

${ }^{\mathrm{b}}$ Takahashi et al. [24]

${ }^{\mathrm{c}}$ Duxbury et al. [33]

d Jeffery et al. [20] 
Total protein concentration was measured using the BCA assay kit (Pierce, IL, USA) and absorbance measured at $560 \mathrm{~nm}$ (Spectra Rainbow spectrophotometer, X-Read Plus version 4.3).

\section{Human Ghrelin Enzyme Immunoassay (EIA)}

Ghrelin levels in cell lysates were determined using a ghrelin EIA kit (RayBiotech, Norcross, GA, USA) according to the manufacturer's protocol. The detection limit was $161 \mathrm{pg} / \mathrm{ml}$, with $15 \%$ inter-assay coefficient of variation $(\mathrm{CV})$ and $10 \%$ intra-assay $\mathrm{CV}$. Briefly, cell lysates $(5 \mu \mathrm{g})$ or recombinant human ghrelin standard peptide at different concentrations, $100 \mu \mathrm{l}$ ghrelin polyclonal antibody and $10 \mathrm{ng} / \mathrm{ml}$ biotinylated ghrelin peptide were added to each well. After $2.5 \mathrm{~h}$ of incubation, the plates were washed and the immunoreactivity was determined using the horseradish peroxidise (HRP)-streptavidin-tetramethylbenzidine (TMB) detection system. The reactions were stopped by addition of $50 \mu \mathrm{l} 2 \mathrm{M}$ sulphuric acid and absorbance at $450 \mathrm{~nm}$ was determined using a 96-well plate reader (Spectra Rainbow spectrophotometer, X-Read Plus version 4.3). Ghrelin concentration in the samples was determined by comparing their absorbance to the standard curve. All standards and samples were analysed in triplicate.

\section{Western Blotting}

Cultured cell lysates $(30 \mu \mathrm{g})$ were denatured at $95^{\circ} \mathrm{C}$ for $10 \mathrm{~min}$ in $2 \times$ sample buffer $[250 \mathrm{mM}$ Tris- $\mathrm{Cl}(\mathrm{pH} 6.8)$, $2 \%$ sodium dodecyl sulfate, $10 \%$ glycerol, $20 \mathrm{mM}$ dithiothreitol and $0.01 \%$ bromophenol blue]. Proteins were separated by $10 \%$ SDS-PAGE and electrotransferred onto nitrocellulose membranes (Schleicher and Schuell, Dassel, Germany). The membranes were blocked for $1 \mathrm{~h}$ with $2.5 \%$ skim milk powder-Tris buffered saline-Tween 20 (2.5\% SMP-TBS-T) prior to incubation with a polyclonal goat anti-human GHSR1a primary antibody $(1: 1,000$ in $2.5 \%$ SMP-TBS-T; Santa Cruz Biotechnology, Inc., Santa Cruz, CA, USA) overnight at $4^{\circ} \mathrm{C}$. Membranes were washed $3 \times 10 \mathrm{~min}$ in TBS-T and incubated for $1 \mathrm{~h}$ at room temperature with donkey anti-goat HRP secondary antibody (1:2,000 in 2.5\% SMP-TBS-T; Jackson ImmunoResearch, West Grove, PA, USA) followed by detection with enhanced chemiluminescence (Pierce) according to the manufacturer's instructions. After Western blotting for GHSR1a, membranes were stripped and re-probed with the $\beta$-tubulin internal control antibody $(1: 500$ in $2.5 \%$ SMP-TBS-T; Abcam) to ensure equal protein loading and allow semi-quantitative densitometry analysis on scanned films using ImageJ software [26].

\section{Cell Proliferation Assay}

Cells were seeded in 96-well plates at a density of $2 \times 10^{4}$ cells per well and cultured in presence or absence of human $n$-octonylated (acylated) ghrelin (ProSpec-Tany TechnoGene Ltd., Rehovot, Israel) over a range of concentrations between 0.1 and 1,000 nM. Medium was replaced every $24 \mathrm{~h}$ for both treated and untreated cells. After 24, 48 or $72 \mathrm{~h}$, cells were incubated with CellTiter $96^{\circledR} \mathrm{AQ}$ ueous One Solution Reagent (Promega, Madison, WI, USA), which contains tetrazolium compound [3-(4,5-dimethylthiazol2-yl)5-(3-carboxymethoxyphenyl)-2-(4-sulfophenyl)-2H-tetrazolium, inner salt] (MTS), according to the manufacturer's instructions. Cell proliferation was quantified by measuring absorbance at $490 \mathrm{~nm}$ (Spectra Rainbow spectrophotometer, X-Read Plus version 4.3) and expressed as percentage relative to untreated control. Each experiment provided six replicates and the experiments were repeated four times.

\section{Flow Cytometry}

Cells were seeded in six-well plates at a density at $5 \times 10^{5}$ cells per well. Cells were cultured in doxorubicin, a potent inducer of apoptosis in cancer cell lines [27-29]. In order to determine the effect of ghrelin treatment on cancer cell apoptosis, cells were cultured in $10 \mathrm{nM}$ doxorubicin alone or in the presence of human $n$-octonylated (acylated) ghrelin $(0.1,1$ and $10 \mathrm{nM})$ or without ghrelin (control) for $72 \mathrm{~h}$. Medium was replaced every $24 \mathrm{~h}$ for both treated and untreated cells. The cell apoptosis assay was carried out using the ApoTarget Annexin-V FITC Apoptosis Kit (Invitrogen) according to manufacturer's instructions. Briefly, the cells were double stained with Annexin V-FITC and propidium iodide (PI) and then analysed on a flow cytometry (BD LSR II Analyser). Three populations of cells were distinguishable by the flow cytometry: (1) non-apoptotic cells, which were Annexin-V negative and PI negative; (2) early apoptotic cells (Annexin-V positive and PI negative); and (3) late apoptotic/necrotic cells (Annexin-V positive and PI positive). Cell apoptosis was expressed as percentage relative to untreated control. All experiments were performed three times with triplicate cultures.

\section{Statistical Analyses}

Data are expressed as mean \pm standard error of mean (SEM). Statistical significance was determined using one-way analysis of variance with Tukey's post hoc analysis, with a $P$ value $<0.05$ considered to be statistically significant. Analyses were conducted by GraphPad Prism software (Prism 5; GraphPad Software, La Jolla, CA, USA). 
Fig. 1 Relative expression of ghrelin $(G H R L)$ in normal endometrium and endometrial carcinoma by quantitative realtime RT-PCR. Data were normalised to $\beta$-actin and are represented as fold changes relative to expression of transcripts in a normal endometrial tissue sample (1.0)

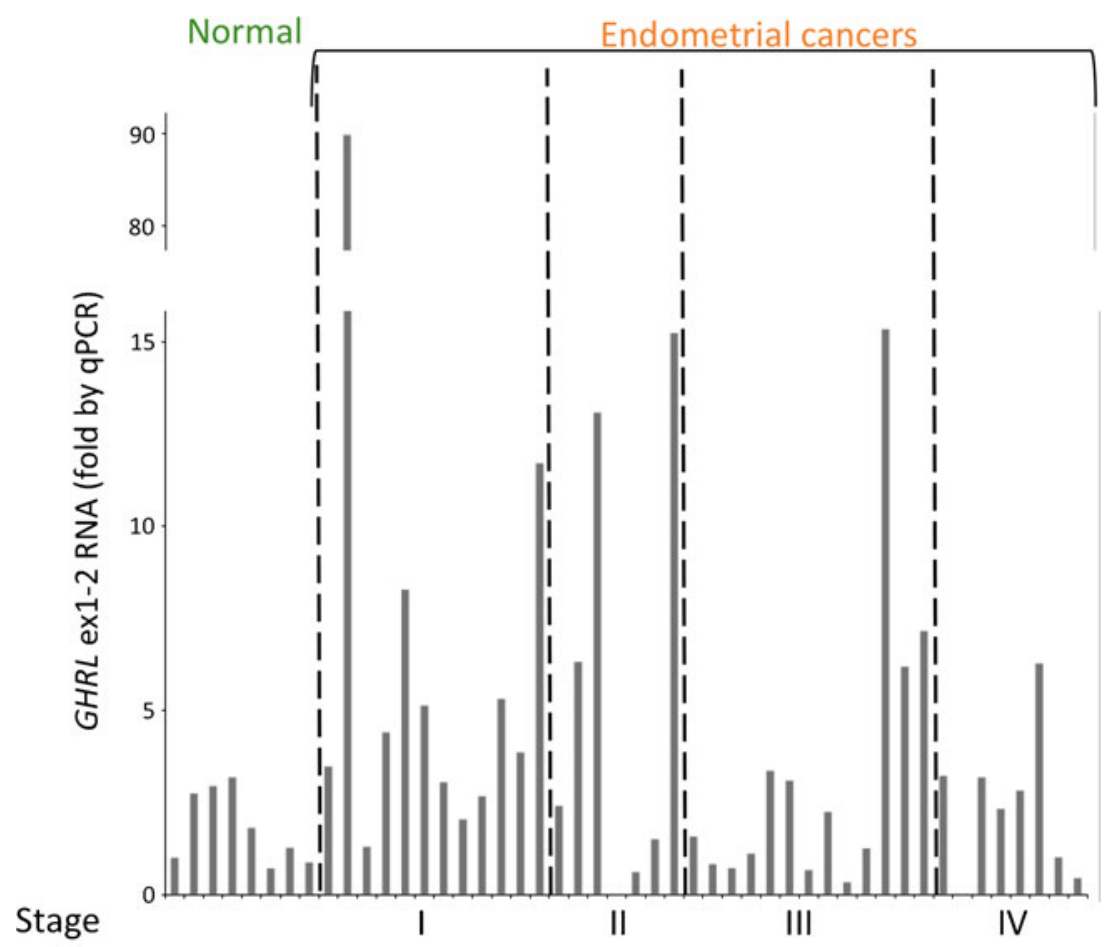

\section{Results}

Expression of the Ghrelin Axis in Normal and Tumour Endometrial Tissue

We examined the expression of ghrelin and its functional receptor, GHSRla, in a range of clinical endometrial samples. Quantitative real-time RT-PCR of tissue from normal endometrium (eight samples) and various stages of endometrial cancer (40 samples) demonstrated that ghrelin is expressed in normal endometrium and highly expressed in a range of endometrial cancers, although no correlation could be discerned between cancer stage and gene expression (Fig. 1). In contrast, the known ghrelin receptor, GHSR 1a, was expressed at a low level in most of samples with high expression in a small number of the normal and cancer endometrial specimens tested (data not shown).

\section{Ghrelin and GHSR Expression in Cultured Endometrial Cancer Cells}

Having confirmed that ghrelin mRNA is expressed in normal endometrium and in endometrial cancer, we examined the expression of the ghrelin axis in an in vitro cell culture system. RT-PCR analysis demonstrated the expression of ghrelin, GHSR $1 a$ and GHSR $1 b$ mRNA in the three endometrial cancer cell lines examined (Fig. 2).

Next, we examined the expression of the ghrelin axis in three endometrial cancer cell lines by quantitative real-time
RT-PCR and Western blot analyses. Ghrelin, GHSR $1 a$ and GHSR 1b mRNA expression was the highest in the poorly differentiated KLE cell line (Fig. 3). Ghrelin mRNA expression in the KLE cell line was significantly higher than in the moderately differentiated HEC1B cell line $(P<0.05$; Fig. 3a). KLE cells displayed a 2.6-fold increase in ghrelin mRNA compared to the well-differentiated Ishikawa endometrial cancer cell line, but this was not statistically

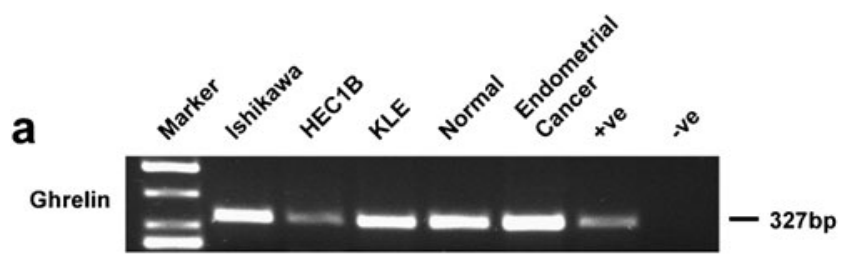

b

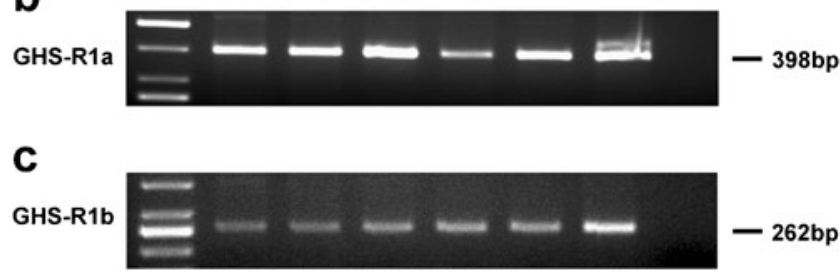

Fig. 2 Representative ethidium bromide stained agarose gels showing RT-PCR products of the expected length for a ghrelin, b GHSRI $a$ and c GHSR $1 b$ mRNA, which are expressed in the Ishikawa, HEC1B and KLE endometrial cancer cell lines, in normal endometrial tissue and in endometrial cancer tissue. $M$ marker (GeneRuler ${ }^{\mathrm{TM}} 50$ bp DNA ladder; Fermentas). Positive controls were performed using human stomach cDNA for ghrelin and GHSRIa and MDA-MB-231 breast cancer cell line for GHSRIb. Negative controls were performed by omitting cDNA (no template) in the PCR mixture 

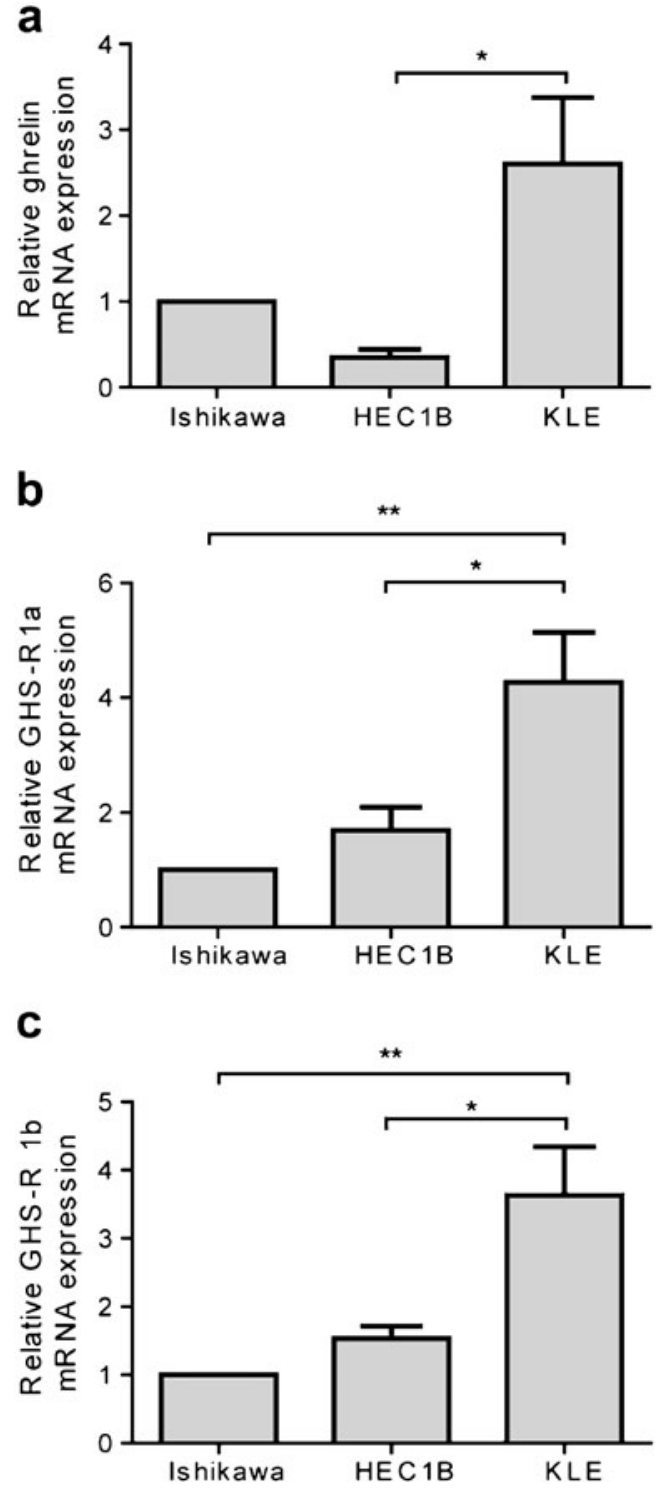

Fig. 3 Quantitative RT-PCR analysis of mRNA expression for ghrelin, GHSRla and GHSRIb in Ishikawa, HEC1B and KLE human endometrial cancer cell lines. The fold change in a ghrelin, b GHSRIa and $\mathbf{c} G H S R 1 b$ mRNA expression after normalization with the internal control, 18S rRNA, and relative to the calibrator Ishikawa cell line. Data represent the mean \pm SEM $(n=3, * * P<0.01, * P<0.05)$

significant (Fig. 3a). Moreover, mRNA expression of both receptor isoforms was strongly correlated with the differentiation status of the cell lines. KLE cells expressed 4-fold $(P<$ 0.01 ) higher GHSRIa mRNA levels, compared to the Ishikawa cell line, and 2.5 -fold $(P<0.05)$ higher than the HEC1B cell line (Fig. 3b). A similar pattern was observed for $G H S R 1 b$ gene expression. KLE cells expressed 3.6-fold $(P<$ 0.01 ) higher GHSRIb mRNA than the Ishikawa cell line and 2.4-fold $(P<0.05)$ higher than the HEC1B cell line (Fig. 3c).

Western blot analyses of protein extracts from the endometrial cancer cell lines revealed GHSR1a expression at approximately $44 \mathrm{kDa}$ (Fig. 4a, b). As shown in Fig. 4c,
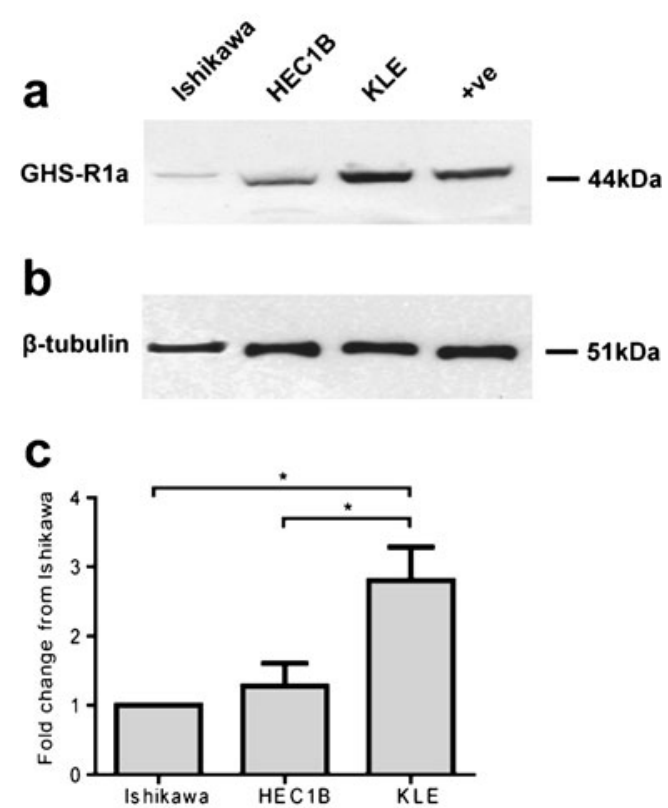

Fig. 4 Western blot analysis showing GHSR1a protein expression in endometrial cancer cell lysates. a A 44-kDa immuno-reactive band, the expected size of the GHSR1a, is observed in all of the cell lines. MDA-MB-435 breast cancer cell lysate was used as positive control. b Total protein loading was assessed by blotting with $\beta$-tubulin antibody. c Densitometry, corrected for protein loading, was used to compare the level of expression compared to GHSR1a expression in the Ishikawa cell line $(n=3, * P<0.05)$. Data represent the mean \pm SEM

GHSR1a protein expression (compared to the internal control) was found to be significantly associated with the differentiation status of the cell lines. The poorly differentiated KLE endometrial cancer cell line showed 2.8-fold higher GHSR1a expression compared to the welldifferentiated Ishikawa cell line $(P<0.05)$ and 2.5-fold higher levels than moderately differentiated HEC $1 B$ endometrial cancer cell line $(P<0.05)$. Next, ghrelin content of endometrial cancer cell lysates were measured by enzyme immunoassay (EIA). Mean ghrelin levels were the highest in KLE endometrial cancer cell lines $(386.3 \pm 35.3 \mathrm{ng} / \mathrm{ml})$ compared with Ishikawa $(222.7 \pm 22.3 \mathrm{ng} / \mathrm{ml} ; P<0.05)$ and HEC1B cell lines $(185.1 \pm 37.4 \mathrm{ng} / \mathrm{ml} ; P<0.05)$ as shown in Fig. 5 .

Stimulation of Endometrial Cancer Cell Proliferation by Ghrelin

The Ishikawa, HEC1B and KLE endometrial cancer cell lines were cultured in vitro and exposed to various concentrations of acylated ghrelin $(0.1-1,000 \mathrm{nM})$ for 24 , 48 and $72 \mathrm{~h}$, and the effect of ghrelin treatment on cell proliferation was examined using an MTS assay. Ghrelin promoted cell proliferation in a dose- and time-dependent manner. Incubation with a range of ghrelin concentrations did not significantly affect cell proliferation at the 24- or 48-h time point (data not shown). A significant increase in 


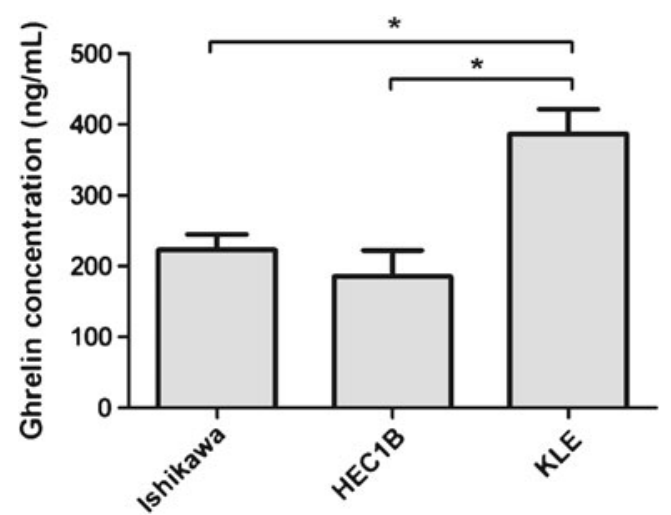

Fig. 5 Ghrelin expression in endometrial cancer cell line lysates was quantified by EIA. The absorbance from cell lysates was compared the absorbance of the samples to the standard curve. Data represent the mean $\pm \operatorname{SEM}(n=3, * P<0.05)$. The fold difference in ghrelin concentration compared to the Ishikawa cell line was also determined

cell proliferation of $19-30 \%$ above control was observed after $72 \mathrm{~h}$ of treatment (Fig. 6) even at $1 \mathrm{nM}$ concentrations of ghrelin treatment for Ishikawa and KLE cells (Fig. 6a, c). The peak stimulatory effect was at $100 \mathrm{nM}$ ghrelin, which significantly increased cell proliferation by $25 \%$ in Ishikawa cells $(P<0.01$; Fig. 6a) by $28 \%$ in HEC1B cells $(P<0.01$; Fig. 6 b) and by $30 \%$ in the KLE endometrial cancer cell line $(P<0.01$; Fig. 6c) compared to the untreated controls.

\section{Ghrelin Protects Endometrial Cancer Cells from Doxorubicin-Induced Cell Death}

To further investigate the stimulatory effect of ghrelin on endometrial cancer cell growth, we examined apoptosis in the cell lines after ghrelin treatment by flow cytometry. Doxorubicin $(10 \mathrm{nM})$ significantly induced early apoptosis in the Ishikawa and HEC1B cell lines $(P<0.05$; data not shown) and late apoptosis/necrosis in all the cell lines, compared to the no-treatment controls $(P<0.05$; Fig. 7b-d). Ghrelin treatment at various concentrations did not prevent early apoptosis, while $10 \mathrm{nM}$ ghrelin significantly suppressed doxorubicin-induced late apoptosis/necrosis from $198.3 \pm 14.4 \%$ to $156.0 \pm 5.9 \%$ of control in Ishikawa cell line $(P<0.05$; Fig. 7 b). A similar pattern was observed in HEC1B and KLE cell lines. The addition of 0.1 and $1 \mathrm{nM}$ ghrelin protected HEC1B cells against doxorubicin-induced late apoptosis/necrosis. The anti-apoptotic effect was maximal at $0.1 \mathrm{nM}$ and decreased apoptosis from $149.1 \pm$ $7.4 \%$ to $113.4 \pm 5.0 \%$ of control $(P<0.05$; Fig. $7 \mathrm{c})$. Similarly, $0.1-10 \mathrm{nM}$ ghrelin protected KLE cells against late apoptosis/necrosis induced by doxorubicin and was most effective at $10 \mathrm{nM}$ ghrelin, which decreased apoptosis from $212.7 \pm 28.7 \%$ to $93 \pm 13.8 \%$ of control $(P<0.01$; Fig. 7 d). These results show that ghrelin treatment had a dosedependent, anti-apoptotic effect on the human endometrial cancer cell lines treated with doxorubicin.

\section{Discussion}

There is emerging evidence which suggests that ghrelin is an autocrine/paracrine growth factor in some cancers. Ghrelin expression has been detected in a number of different cancers, including breast [20], testicular [21], prostate [22] and colorectal cancers [30]. Human endometrium is an unusual adult tissue as it undergoes extensive remodelling throughout the reproductive cycle. Both ghrelin and GHSR mRNA and protein are expressed in the proliferative, secretory and menstrual phases of the human endometrium [12]. Maximal levels are expressed during the
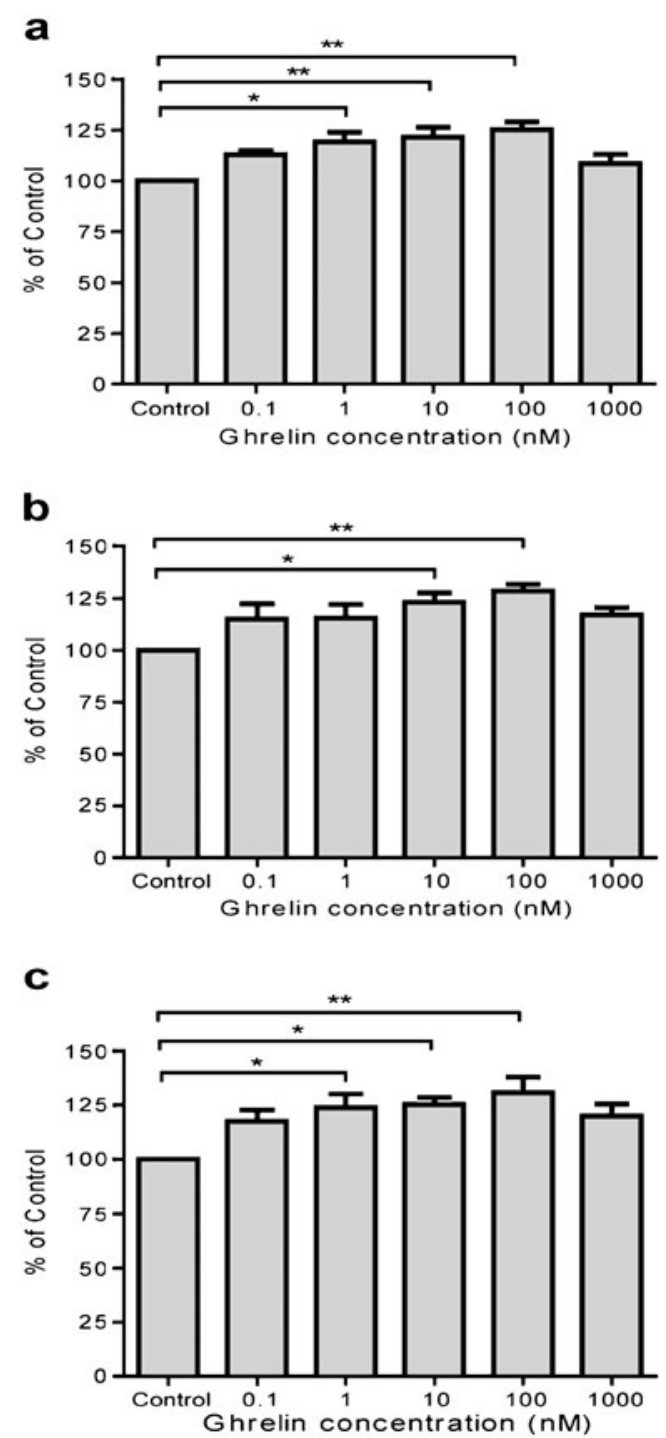

Fig. 6 Effect of exogenous ghrelin on a Ishikawa, b HEC1B and c KLE human endometrial cancer cell proliferation, measured using the MTS proliferation assay. Cells were incubated with ghrelin treatment $(0-1,000 \mathrm{nM})$ for $72 \mathrm{~h}$. Absorbance readings for each treatment were converted to percentages of control. Data are derived from four experiments with six replicates per condition and represented as the mean \pm SEM $(* * P<0.01 ; * P<0.05)$ 

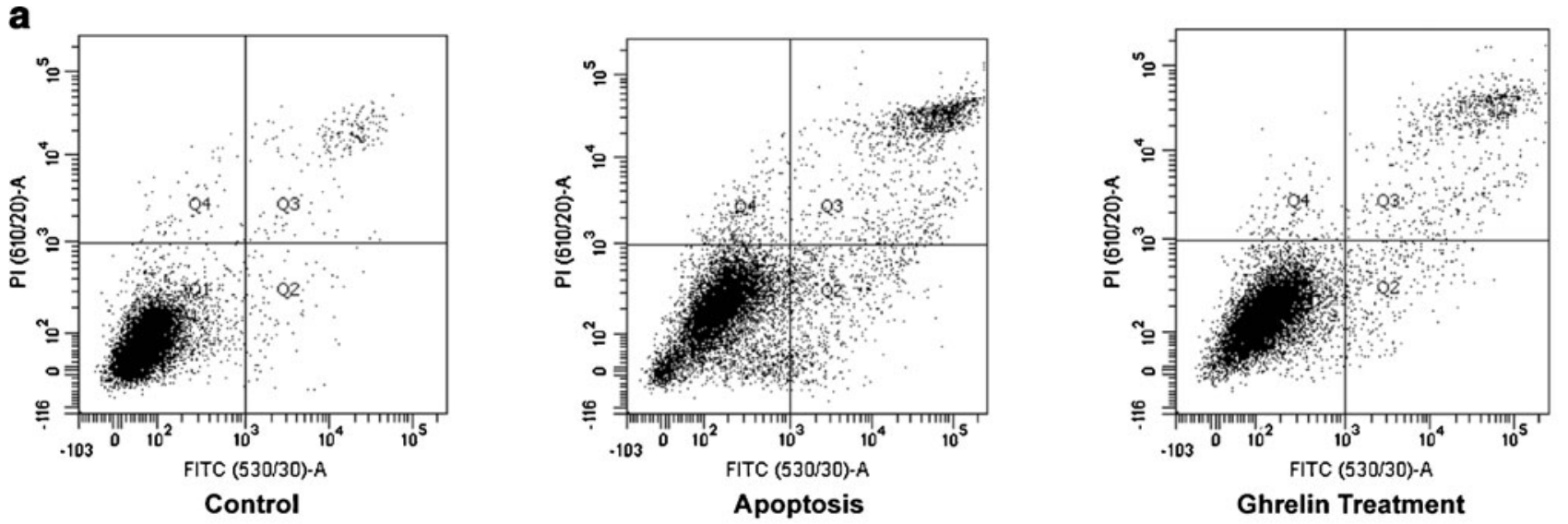

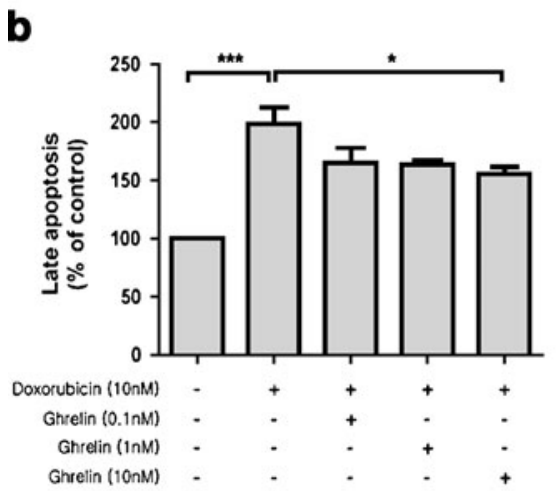

Ishikawa

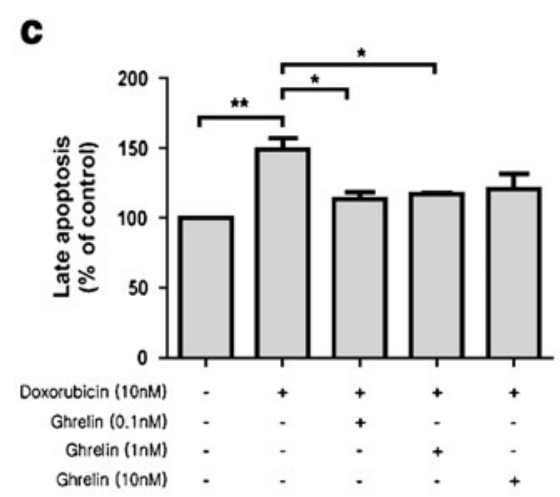

HEC1B

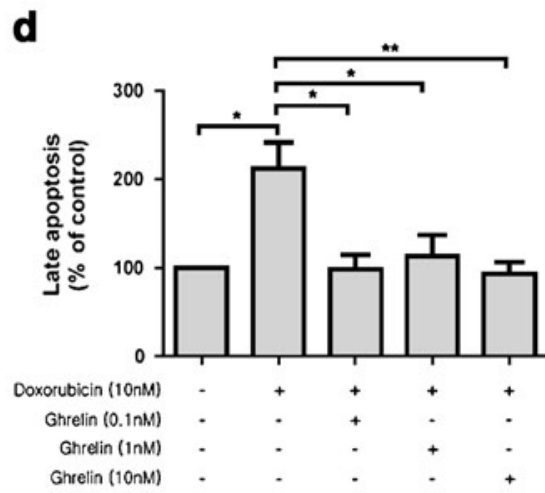

KLE
Fig. 7 Anti-apoptotic effect of ghrelin on $\mathbf{a}-\mathbf{b}$ Ishikawa, $\mathbf{c}$ HEC1B and d KLE endometrial cancer cells. Cells were incubated with $10 \mathrm{nM}$ doxorubicin alone or in presence of ghrelin treatment $(0.1-10 \mathrm{nM})$ for $72 \mathrm{~h}$. a The dot plots show Ishikawa cell line incubated with no treatment, apoptosis inducer or $10 \mathrm{nM}$ ghrelin treatment. Three populations of cells were distinguishable by the flow cytometry. $Q 1$ non-apoptotic cells: Annexin-V negative and PI negative; $Q 2$ early

secretory phase, where the endometrium is receptive to implantation [12]. This suggests that ghrelin regulates endometrial growth and differentiation, and that various pathophysiological conditions may result from an imbalance of ghrelin peptide hormone levels. Therefore, in the present study we examined the expression and function of the ghrelin axis in endometrial cancer.

Our data show that ghrelin mRNA is expressed in normal endometrial tissues and highly expressed in a range of endometrial cancer tissues, although this does not appear to correlate with the clinical stage of the samples examined. A recent immunoassay-based study showed that ghrelin is expressed in proliferative endometrium, while very low levels were found in stage 2 endometrial adenocarcinoma tissues [31]. Interestingly, from all the cell lines examined in our study, this is consistent with the lowest ghrelin mRNA and protein levels observed in the HEC1B cell line, which is derived from grade 2 human endometrial adenocarcinoma [32]. Further studies are warranted to apoptotic cells: Annexin-V positive and PI negative; $Q 3$ late apoptotic/ necrotic cells: Annexin-V positive and PI positive. The bar graphs show the percentage changes of $\mathbf{b}-\mathbf{d}$ late apoptotic/necrotic cells of controls. Data are derived from three experiments with triplicates per condition and represented as the mean \pm SEM $(* * * P<0.001 ; * * P<0.01$; $* P<0.05)$

determine if the up-regulation of ghrelin expression is restricted to a specific subset of endometrial tumours. However, we found that the mRNA expression levels of GHSR1a and GHSR1b correlate with the differentiation status of the endometrial cell lines studied, with higher levels expressed in the less-differentiated cell lines. Further studies are needed to investigate if the ghrelin axis plays a role in the regulation of cell differentiation in endometrial cancer.

To investigate the function of ghrelin in endometrial cancer, we examined the effect of ghrelin treatment on cell proliferation in vitro and demonstrated that ghrelin increases proliferation in endometrial cancer cell lines, regardless of their differentiation status. This suggests that ghrelin plays an autocrine role in endometrial cancer. These data are consistent with the previous studies showing that exogenous ghrelin stimulates proliferation in breast [20], prostate [23], pancreatic [33], adrenal cortical [34] and liver cancer cell lines [35] as well as a number of normal cell 
lines [36-38]. We also found that the proliferative effect of ghrelin may be dose dependent, with a peak effect occurring at $100 \mathrm{nM}$. Moreover, 1,000 nM ghrelin inhibited proliferation, suggestive of cytotoxic effects or receptor desensitisation. This observation is consistent with previous studies in other cancer cell lines where ghrelin-induced cell proliferation was inhibited at high concentrations of the peptide $[20,23,33]$.

The coordination and balance between cell proliferation and apoptosis is crucial for normal development. Cancer results when clones of mutated cells survive and proliferate inappropriately, disrupting this balance [39]. We have demonstrated that ghrelin protects against doxorubicininduced apoptosis in the endometrial cell lines examined. Other studies have demonstrated that ghrelin treatment stimulates the anti-apoptotic pathways in human adrenocortical tumour cells [34] and an oesophageal adenocarcinoma cell line [40]. Ghrelin is anti-apoptotic in human islet cells [41] and endothelial cells [42] and also in a range of rodent cell types including cardiomyocytes [43], pancreatic beta cells [41, 44-46], adipocytes [47], neuronal cells [48, 49] and osteoblastic cells [37].

While the cause of endometrial cancer is unknown, it is well known that changes in hormone balance in women at menopause increase the risk of endometrial cancer. A recent study demonstrated that serum ghrelin levels are markedly higher in the women at peri-menopause compared to both pre-menopausal and post-menopausal stages [50]. Interestingly, increased plasma acylated ghrelin levels have been reported in women with uterine leiomyoma [51]. As we have demonstrated that ghrelin increases proliferation and inhibits apoptosis in endometrial cancer cell lines, we suggest that increased circulating ghrelin in women undergoing menopause may be an important factor in the development, maintenance and progression of human endometrial cancer. Clinical studies determining serum ghrelin levels are, therefore, required to evaluate its potential role as a diagnostic and/or prognostic marker for endometrial cancer.

To date, two growth hormone secretagogue receptors (generated by alternative splicing) have been cloned in humans: the full-length type GHSR1a and the truncated GHSR 1b receptor [52]. The GHSR1a is a seven transmembrane domain, $G$ protein-coupled receptor with highaffinity ghrelin binding and signal transduction capacity. In contrast, GHSR $1 b$ has only five transmembrane domains and does not bind any growth hormone secretagogues [16]. Our data show that ghrelin is expressed in endometrial cancer tissue and cell lines. GHSR1a is expressed by the three endometrial cancer cell lines examined, but only expressed at high levels in a small number of normal endometrial and endometrial cancer specimens. The limited expression of GHSR1a in clinical samples suggests that the co-expression of ghrelin and GHSR1a may only contribute to the promotion of tumour growth in particular cancer subtypes. Ghrelin could promote endometrial cancer progression by alternative, not yet identified receptor(s). Indeed, there is strong evidence that orphan receptor(s) can bind un-acylated (des-ghrelin), (acylated) ghrelin or both forms of ghrelin [43, 53-59].

We also demonstrated that GHSR $1 \mathrm{~b}$ mRNA is expressed by the three endometrial cancer cell lines examined and expression levels were higher in the less-differentiated cell lines. GHSR $1 b$ is not activated by ghrelin, but paradoxically, is expressed in many tumours, including breast, prostate, adrenal and lung cancers, where it is often expressed at higher levels than the GHSR1a isoform [18, 20, 22, 24, 60]. As GHSR1b does not bind ghrelin, its primary role may be as a modulator of other $G$ proteincoupled receptors (GPCRs) by increasing internalisation of GHSR1a [61-63] and by forming novel GPCR combinations by heterodimerisation [24]. Deducing the receptor(s) and signalling pathways for ghrelin as well as the role of GHSR $1 b$ in endometrial cancer are most important future studies.

In conclusion, this study has described the expression of the ghrelin axis in endometrial cancer tissues and cell lines, and provides functional evidence that ghrelin promotes proliferation and inhibits apoptosis in endometrial cancer cell lines. Ghrelin is expressed in endometrial cancer and may, therefore, play a role in several processes related to endometrial cancer progression. This suggests that antagonists of this peptide may have therapeutic value in the treatment of endometrial cancer.

Acknowledgements This work was supported by grants from National Health and Medical Research Council (NHMRC) (to CC), the Cancer Council Queensland (to CC and LKC), the University of Queensland (to CC), the Queensland University of Technology (to LKC) and a Queensland University of Technology Early Career Researcher grant (to IS). We would like to thank Professor Fang Fang, Drs Yi Zhang, Heng Zou and Xiaoling Gan (West China Second Hospital, Sichuan University) and Drs Peta Fairweather and Nick Musgrave from Sullivan and Nicolaides Pathology for assistance in tissue collection.

Declaration of Interest The authors declare that they have no conflict of interest.

\section{References}

1. Jemal A, Siegel R, Ward E, Hao Y, Xu J, Murray T, Thun MJ (2008) Cancer statistics, 2008. CA Cancer J Clin 58:71-96

2. Kitchener H (2006) Management of endometrial cancer. Eur J Surg Oncol 32:838-843

3. Bansal N, Yendluri V, Wenham RM (2009) The molecular biology of endometrial cancers and the implications for pathogenesis, classification, and targeted therapies. Cancer Control 16:8-13 
4. Hess AP, Hamilton AE, Talbi S, Dosiou C, Nyegaard M, Nayak N, Genbecev-Krtolica O et al (2007) Decidual stromal cell response to paracrine signals from the trophoblast: amplification of immune and angiogenic modulators. Biol Reprod 76:102-117

5. Tabibzadeh S (1996) The signals and molecular pathways involved in human menstruation, a unique process of tissue destruction and remodelling. Mol Hum Reprod 2:77-92

6. Gunter MJ, Hoover DR, Yu H, Wassertheil-Smoller S, Manson JE, Li J, Harris TG et al (2008) A prospective evaluation of insulin and insulin-like growth factor-I as risk factors for endometrial cancer. Cancer Epidemiol Biomark Prev 17:921929

7. Berstein LM, Tchernobrovkina AE, Gamajunova VB, Kovalevskij AJ, Vasilyev DA, Chepik OF, Turkevitch EA et al (2003) Tumor estrogen content and clinico-morphological and endocrine features of endometrial cancer. J Cancer Res Clin Oncol 129:245-249

8. Ito K, Utsunomiya H, Yaegashi N, Sasano H (2007) Biological roles of estrogen and progesterone in human endometrial carcinoma - new developments in potential endocrine therapy for endometrial cancer. Endocr J 54:667-679

9. Schally AV, Varga JL, Engel JB (2008) Antagonists of growthhormone-releasing hormone: an emerging new therapy for cancer. Nat Clin Pract Endocrinol Metab 4:33-43

10. Zhao L, Yano T, Osuga Y, Nakagawa S, Oishi H, Wada-Hiraike O, Tang X et al (2008) Cellular mechanisms of growth inhibition of human endometrial cancer cell line by an antagonist of growth hormone-releasing hormone. Int J Oncol 32:593-601

11. Tanaka K, Minoura H, Isobe T, Yonaha H, Kawato H, Wang DF, Yoshida T, Kojima M, Kangawa K, Toyoda N (2003) Ghrelin is involved in the decidualization of human endometrial stromal cells. J Clin Endocrinol Metab 88:2335-2340

12. Tawadros N, Salamonsen LA, Dimitriadis E, Chen C (2007) Facilitation of decidualization by locally produced ghrelin in the human endometrium. Mol Hum Reprod 13:483-489

13. Budak E, Fernandez Sanchez M, Bellver J, Cervero A, Simon C, Pellicer A (2006) Interactions of the hormones leptin, ghrelin, adiponectin, resistin, and PYY3-36 with the reproductive system. Fertil Steril 85:1563-1581

14. Aghajanova L, Rumman A, Altmae S, Wanggren K, StavreusEvers A (2010) Diminished endometrial expression of ghrelin and ghrelin receptor contributes to infertility. Reprod Sci $17: 823-832$

15. Kojima M, Hosoda H, Date Y, Nakazato M, Matsuo H, Kangawa K (1999) Ghrelin is a growth-hormone-releasing acylated peptide from stomach. Nature 402:656-660

16. Howard AD, Feighner SD, Cully DF, Arena JP, Liberator PA, Rosenblum CI, Hamelin M et al (1996) A receptor in pituitary and hypothalamus that functions in growth hormone release. Science 273:974-977

17. Ghelardoni S, Carnicelli V, Frascarelli S, Ronca-Testoni S, Zucchi R (2006) Ghrelin tissue distribution: comparison between gene and protein expression. J Endocrinol Invest 29:115-121

18. Gnanapavan S, Kola B, Bustin SA, Morris DG, McGee P, Fairclough $\mathrm{P}$, Bhattacharya $\mathrm{S}$, Carpenter $\mathrm{R}$, Grossman $\mathrm{AB}$, Korbonits M (2002) The tissue distribution of the mRNA of ghrelin and subtypes of its receptor, GHS-R, in humans. J Clin Endocrinol Metab 87:2988

19. Gualillo O, Caminos J, Blanco M, Garcia-Caballero T, Kojima M, Kangawa K, Dieguez C, Casanueva F (2001) Ghrelin, a novel placental-derived hormone. Endocrinology 142:788-794

20. Jeffery PL, Murray RE, Yeh AH, McNamara JF, Duncan RP, Francis GD, Herington AC, Chopin LK (2005) Expression and function of the ghrelin axis, including a novel preproghrelin isoform, in human breast cancer tissues and cell lines. Endocr Relat Cancer 12:839-850

21. Gaytan F, Barreiro ML, Caminos JE, Chopin LK, Herington AC, Morales C, Pinilla L et al (2004) Expression of ghrelin and its functional receptor, the type 1a growth hormone secretagogue receptor, in normal human testis and testicular tumors. J Clin Endocrinol Metab 89:400-409

22. Jeffery PL, Herington AC, Chopin LK (2002) Expression and action of the growth hormone releasing peptide ghrelin and its receptor in prostate cancer cell lines. J Endocrinol 172:R7-R11

23. Yeh AH, Jeffery PL, Duncan RP, Herington AC, Chopin LK (2005) Ghrelin and a novel preproghrelin isoform are highly expressed in prostate cancer and ghrelin activates mitogenactivated protein kinase in prostate cancer. Clin Cancer Res 11:8295-8303

24. Takahashi K, Furukawa C, Takano A, Ishikawa N, Kato T, Hayama S, Suzuki C et al (2006) The neuromedin U-growth hormone secretagogue receptor $1 \mathrm{~b} /$ neurotensin receptor 1 oncogenic signaling pathway as a therapeutic target for lung cancer. Cancer Res 66:9408-9419

25. Livak KJ, Schmittgen TD (2001) Analysis of relative gene expression data using real-time quantitative PCR and the 2(-Delta Delta C(T)) method. Methods 25:402-408

26. Abramoff MD, Magelhaes PJ, Ram SJ (2004) Image processing with ImageJ. Biophoton Int 11:36-42

27. Li S, Zhou Y, Wang R, Zhang H, Dong Y, Ip C (2007) Selenium sensitizes MCF-7 breast cancer cells to doxorubicin-induced apoptosis through modulation of phospho-Akt and its downstream substrates. Mol Cancer Ther 6:1031-1038

28. Fister S, Schlotawa L, Gunthert AR, Emons G, Grundker C (2008) Increase of doxorubicin-induced apoptosis after knockdown of gonadotropin-releasing hormone receptor expression in human endometrial, ovarian and breast cancer cells. Gynecol Endocrinol 24:24-29

29. Wan X, Li J, Xie X, Lu W (2007) PTEN augments doxorubicininduced apoptosis in PTEN-null Ishikawa cells. Int J Gynecol Cancer 17:808-812

30. Waseem T, Rehman Javaid Ur F, Ahmad MA, Qureshi MA (2008) Role of ghrelin axis in colorectal cancer: a novel association. Peptides 29:1369-1376

31. Dagli AF, Aydin S, Kocdor H, Gurates B, Sahin I, Catak Z, Ozercan MR, Ozercan IH (2010) Ghrelin expression of endometrium hyperplasia and endometrioid carcinoma. Gynecol Endocrinol. doi: $10.3109 / 09513590.2010 .488772$

32. Kuramoto H (1972) Studies of the growth and cytogenetic properties of human endometrial adenocarcinoma in culture and its development into an established line. Acta Obstet Gynaecol Jpn 19:47-58

33. Duxbury MS, Waseem T, Ito $H$, Robinson MK, Zinner MJ, Ashley SW, Whang EE (2003) Ghrelin promotes pancreatic adenocarcinoma cellular proliferation and invasiveness. Biochem Biophys Res Commun 309:464-468

34. Delhanty PJ, van Koetsveld PM, Gauna C, van de Zande B, Vitale G, Hofland LJ, van der Lely AJ (2007) Ghrelin and its unacylated isoform stimulate the growth of adrenocortical tumor cells via an anti-apoptotic pathway. Am J Physiol Endocrinol Metab 293: E302-E309

35. Murata M, Okimura Y, Iida K, Matsumoto M, Sowa H, Kaji H, Kojima M, Kangawa K, Chihara K (2002) Ghrelin modulates the downstream molecules of insulin signaling in hepatoma cells. $\mathrm{J}$ Biol Chem 277:5667-5674

36. Wang DH, Hu YS, Du JJ, Hu YY, Zhong WD, Qin WJ (2009) Ghrelin stimulates proliferation of human osteoblastic TE85 cells via NO/cGMP signaling pathway. Endocr 35:112-117

37. Kim SW, Her SJ, Park SJ, Kim D, Park KS, Lee HK, Han BH, Kim MS, Shin CS, Kim SY (2005) Ghrelin stimulates prolifer- 
ation and differentiation and inhibits apoptosis in osteoblastic MC3T3-E1 cells. Bone 37:359-369

38. Maccarinelli G, Sibilia V, Torsello A, Raimondo F, Pitto M, Giustina A, Netti C, Cocchi D (2005) Ghrelin regulates proliferation and differentiation of osteoblastic cells. J Endocrinol 184:249-256

39. Guo M, Hay BA (1999) Cell proliferation and apoptosis. Curr Opin Cell Biol 11:745-752

40. Konturek PC, Burnat G, Rau T, Hahn EG, Konturek S (2008) Effect of adiponectin and ghrelin on apoptosis of Barrett adenocarcinoma cell line. Dig Dis Sci 53:597-605

41. Granata R, Settanni F, Biancone L, Trovato L, Nano R, Bertuzzi F, Destefanis $S$ et al (2007) Acylated and unacylated ghrelin promote proliferation and inhibit apoptosis of pancreatic beta-cells and human islets: involvement of 3', 5'-cyclic adenosine monophosphate/protein kinase A, extracellular signal-regulated kinase $1 / 2$, and phosphatidyl inositol 3-kinase/Akt signaling. Endocrinology 148:512-529

42. Zhao H, Liu G, Wang Q, Ding L, Cai H, Jiang H, Xin Z (2007) Effect of ghrelin on human endothelial cells apoptosis induced by high glucose. Biochem Biophys Res Commun 362:677-681

43. Baldanzi G, Filigheddu N, Cutrupi S, Catapano F, Bonissoni S, Fubini A, Malan D et al (2002) Ghrelin and des-acyl ghrelin inhibit cell death in cardiomyocytes and endothelial cells through ERK1/2 and PI 3-kinase/AKT. J Cell Biol 159:1029-1037

44. Granata R, Settanni F, Trovato L, Destefanis S, Gallo D, Martinetti M, Ghigo E, Muccioli G (2006) Unacylated as well as acylated ghrelin promotes cell survival and inhibit apoptosis in HIT-T15 pancreatic beta-cells. J Endocrinol Invest 29:RC19$\mathrm{RC} 22$

45. Zhang Y, Ying B, Shi L, Fan H, Yang D, Xu D, Wei Y et al (2007) Ghrelin inhibit cell apoptosis in pancreatic beta cell line HIT-T15 via mitogen-activated protein kinase/phosphoinositide 3-kinase pathways. Toxicology 237:194-202

46. Wang W, Zhang D, Zhao H, Chen Y, Liu Y, Cao C, Han L, Liu G (2010) Ghrelin inhibits cell apoptosis induced by lipotoxicity in pancreatic beta-cell line. Regul Pept 161:43-50

47. Kim MS, Yoon CY, Jang PG, Park YJ, Shin CS, Park HS, Ryu JW et al (2004) The mitogenic and antiapoptotic actions of ghrelin in 3T3-L1 adipocytes. Mol Endocrinol 18:2291-2301

48. Chung H, Kim E, Lee DH, Seo S, Ju S, Lee D, Kim H, Park S (2007) Ghrelin inhibits apoptosis in hypothalamic neuronal cells during oxygen-glucose deprivation. Endocrinology 148:148-159

49. Liu Y, Chen L, Xu X, Vicaut E, Sercombe R (2009) Both ischemic preconditioning and ghrelin administration protect hippocampus from ischemia/reperfusion and upregulate uncoupling protein-2. BMC Physiol 9:17

50. Sowers MR, Wildman RP, Mancuso P, Eyvazzadeh AD, Karvonen-Gutierrez CA, Rillamas-Sun E, Jannausch ML (2008) Change in adipocytokines and ghrelin with menopause. Maturitas 59:149-157

51. Markowska A, Ziolkowska A, Nowinka K, Malendowicz LK (2009) Elevated blood active ghrelin and normal total ghrelin and obestatin concentrations in uterine leiomyoma. Eur J Gynaecol Oncol 30:281-284
52. McKee KK, Palyha OC, Feighner SD, Hreniuk DL, Tan CP, Phillips MS, Smith RG, Van der Ploeg LH, Howard AD (1997) Molecular analysis of rat pituitary and hypothalamic growth hormone secretagogue receptors. Mol Endocrinol 11:415-423

53. Cassoni P, Ghe C, Marrocco T, Tarabra E, Allia E, Catapano F, Deghenghi R, Ghigo E, Papotti M, Muccioli G (2004) Expression of ghrelin and biological activity of specific receptors for ghrelin and des-acyl ghrelin in human prostate neoplasms and related cell lines. Eur J Endocrinol 150:173-184

54. Cassoni P, Papotti M, Ghe C, Catapano F, Sapino A, Graziani A, Deghenghi R, Reissmann T, Ghigo E, Muccioli G (2001) Identification, characterization, and biological activity of specific receptors for natural (ghrelin) and synthetic growth hormone secretagogues and analogs in human breast carcinomas and cell lines. J Clin Endocrinol Metab 86:1738-1745

55. Gauna C, Delhanty PJ, Hofland LJ, Janssen JA, Broglio F, Ross RJ, Ghigo E, van der Lely AJ (2005) Ghrelin stimulates, whereas des-octanoyl ghrelin inhibits, glucose output by primary hepatocytes. J Clin Endocrinol Metab 90:1055-1060

56. Gauna C, Delhanty PJ, van Aken MO, Janssen JA, Themmen AP, Hofland LJ, Culler M, Broglio F, Ghigo E, van der Lely AJ (2006) Unacylated ghrelin is active on the INS-1E rat insulinoma cell line independently of the growth hormone secretagogue receptor type 1a and the corticotropin releasing factor 2 receptor. Mol Cell Endocrinol 251:103-111

57. Neary NM, Druce MR, Small CJ, Bloom SR (2006) Acylated ghrelin stimulates food intake in the fed and fasted states but desacylated ghrelin has no effect. Gut 55:135

58. Thompson NM, Gill DA, Davies R, Loveridge N, Houston PA, Robinson IC, Wells T (2004) Ghrelin and des-octanoyl ghrelin promote adipogenesis directly in vivo by a mechanism independent of the type 1a growth hormone secretagogue receptor. Endocrinology 145:234-242

59. Toshinai K, Yamaguchi H, Sun Y, Smith RG, Yamanaka A, Sakurai T, Date Y et al (2006) Des-acyl ghrelin induces food intake by a mechanism independent of the growth hormone secretagogue receptor. Endocrinology 147:2306-2314

60. Barzon L, Pacenti M, Masi G, Stefani AL, Fincati K, Palu G (2005) Loss of growth hormone secretagogue receptor 1a and overexpression of type $1 \mathrm{~b}$ receptor transcripts in human adrenocortical tumors. Oncology 68:414-421

61. Chan CB, Cheng CH (2004) Identification and functional characterization of two alternatively spliced growth hormone secretagogue receptor transcripts from the pituitary of black seabream Acanthopagrus schlegeli. Mol Cell Endocrinol 214:81-95

62. Chu KM, Chow KB, Leung PK, Lau PN, Chan CB, Cheng CH, Wise $\mathrm{H}$ (2007) Over-expression of the truncated ghrelin receptor polypeptide attenuates the constitutive activation of phosphatidylinositolspecific phospholipase $\mathrm{C}$ by ghrelin receptors but has no effect on ghrelin-stimulated extracellular signal-regulated kinase 1/2 activity. Int J Biochem Cell Biol 39:752-764

63. Leung PK, Chow KB, Lau PN, Chu KM, Chan CB, Cheng CH, Wise $H$ (2007) The truncated ghrelin receptor polypeptide (GHSR1b) acts as a dominant-negative mutant of the ghrelin receptor. Cell Signal 19:1011-1022 